\title{
Influence of typhoons and earthquakes on rainfall-induced landslides and suspended sediments discharge
}

\author{
Guan-Wei Lin $^{\text {a }}$, Hongey Chen ${ }^{\mathrm{a}, *}$, Yi-Hui Chen ${ }^{\mathrm{a}}$, Ming-Jame Horng ${ }^{\mathrm{b}}$ \\ ${ }^{a}$ Department of Geosciences, National Taiwan University, No.1, Section 4, Roosevelt Road, Taipei, Taiwan, ROC \\ ${ }^{\mathrm{b}}$ Water Resource Agency, Ministry of Economic Affairs, Taiwan, ROC
}

Received 1 May 2007; received in revised form 21 October 2007; accepted 3 December 2007

Available online 27 December 2007

\begin{abstract}
The aim of this paper is to present data on the occurrence of landslides triggered by typhoon and earthquake events, and to discuss the basic earthquake triggering mechanisms involved. Four events of typhoon and earthquake triggered landslides in the Chenyoulan River catchment of central Taiwan during 1996 to 2004 were studied in order to identify their controlling factors. The landslides areas were measured by comparing aerial photos taken over the past 18 years, and sediment discharge was counted at hydrometric stations. Investigation results demonstrate that hillslope geomaterials that had been disturbed by strong seismic shaking induced expansion of landslide areas during subsequent events. Analysis of Normalized Difference Vegetation Index (NDVI) also registered the changes of uncovered conditions on the hillslope caused by landsliding. When flow discharge is lower than $100 \mathrm{~m}^{3} \mathrm{~s}^{-1}$, postseismic sediment concentration is roughly four times higher than pre-seismic concentration with the same flow discharge. This fate indicates that the amount of sediment discharge at normal flow discharge is affected by supplied sediment volume, which tends to increase with seismic activity.
\end{abstract}

(C) 2007 Elsevier B.V. All rights reserved.

Keywords: Landslide; Sediment discharge; Rainstorm; Earthquake

\section{Introduction}

Previous studies (Geli et al., 1988; Sitar et al., 1992; Chen and Su, 2001; Sklar and Dietrich, 2001; Khazai and Sitar, 2004) identify material strength, discontinuous plane setting, earthquake, precipitation, landform and hydrology as the principal natural controls that affect landslides and debris flows. Dadson et al. (2003) reassess sediment discharge in estimating the erosion rate in Taiwan. They consider that the decadal-scale erosion rates are correlated with historical earthquakes and storm-driven runoff, and that long scale erosion rates are controlled by stream power. The average erosion rate in the Choshui River basin, central Taiwan, increased fourfold following the 1999 Chi-Chi earthquake $\left(M_{\mathrm{w}}=7.6\right)$.

On average, four typhoons sweep and inundate Taiwan per year, and the subtropical climate there entails a mean precipitation of $2500 \mathrm{~mm} \mathrm{yr}^{-1}$ (Shieh, 2000). The summer precipitation,

\footnotetext{
* Corresponding author. Tel.: +886 2 33662946; fax: +886 223636095
}

E-mail address: hchen@ntu.edu.tw (H. Chen). occurring from May to October, causes large-scale wasting from hillslope areas. In most years, this precipitation induces several floods and even vast overland flow drives of colluvial sediments into the river channels.

During the period of 1996-2004, the following sequence of events occurred in the central Taiwan (Fig. 1): (1) typhoon Herb (August 1996); (2) Chi-Chi earthquake (September 1999); (3) typhoon Toraji (July 2001); and (4) typhoon Mindulle (June 2004). In the Chenyoulan River catchment, landslides increased by 1.5 times and 44 new debris flows emerged during typhoon Herb in July 1996. After the 1999 Chi-Chi earthquake, an area of approximately $12.9 \times 10^{6} \mathrm{~m}^{2}$ was affected by landsliding in the Chenyoulan River basin. The Chenyoulan River catchment is a tributary of the Choshui River in central Taiwan, located about $12 \mathrm{~km}$ east of the epicentral area of the 1999 Chi-Chi earthquake. However, by the 2001 typhoon Toraji and the 2004 typhoon Mindulle, the landslide area expanded to $24.4 \times 10^{6} \mathrm{~m}^{2}$ and $31.6 \times 10^{6} \mathrm{~m}^{2}$, respectively. This fact implies that the main cause of the expanding landslide area was the disturbance of geomaterial by strong earthquakes. By studying the landsliding 


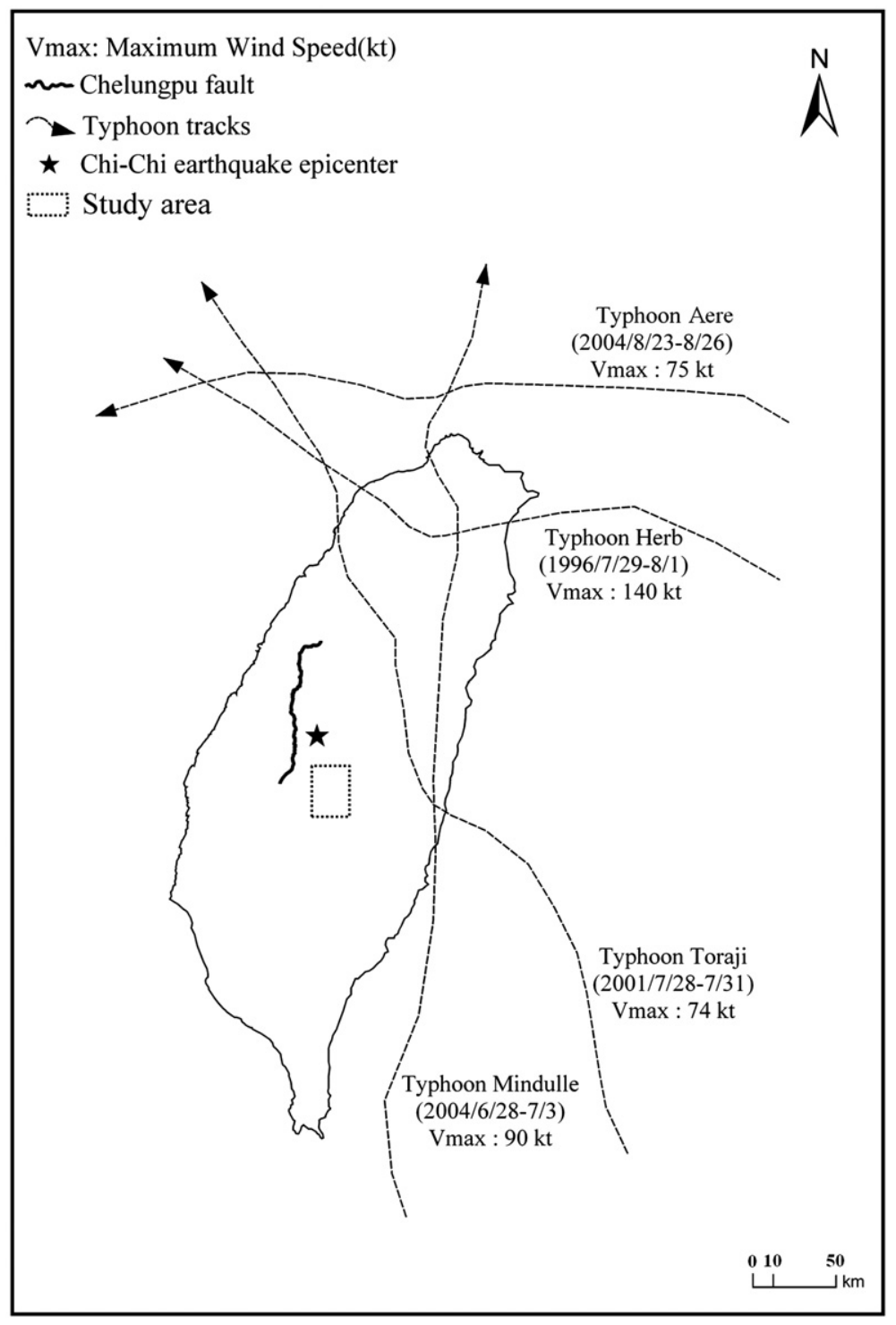

Fig. 1. Tracks of typhoon and the location of Chi-Chi earthquake epicenter.

and the changes of the sediment discharge, we attempt to arrive at an understanding of the seismic effect of the sediment transportation and the strength of the hillslope materials with the impact factor of landsliding.

\section{Geological setting of study area}

The Chenyoulan River in Nantou County is $42 \mathrm{~km}$ in total length and the area of the Chenyoulan River basin is $367 \mathrm{~km}^{2}$; its margin is a mountain range watershed with longitudinal valley topography. The Chenyoulan River originates in a brook on Yushan Mountain. The Chenyoulan River basin is, for the most part, over $2000 \mathrm{~m}$ in elevation, gradually decreasing from south to north.

The river network in the southwestern part of the Chenyoulan River basin includes three tributaries which converge northwardly into the Hoshe River at Shenmu, and several brooks that feed into the main stream of the Hoshe River until this later converges into the main stream of the
Chenyoulan River in the Hoshe area (Fig. 2). The tributaries converge at the center valley of the basin, and then are delivered northward into the Choshui River.

The Chenyoulan River basin lies at the junction where the metamorphic Shuehshan Range keeps abreast the sedimentary Western Foothills (Fig. 2). The Chenyoulan River, closely runs along the Chenyoulan fault line, the major boundary separating these two geological regions. The terrain to the east of the Chenyoulan fault is classified as Paleogene metamorphic rock of the Shuehshan Range, composed of slate and metasandstone. The major formations of east Chenyoulan fault are Lushan Formation, Chiayang Formation, Tachien Sandstone Shihpachuangchi Formation, Shuichangliu Formation, and Paileng Formation.

Lushan Formation, located in the eastern edge of the Chenyoulan River basin and composed mainly of gray slate and a little fine sandstone, has strikes of $\mathrm{N} 5^{\circ} \mathrm{E}-\mathrm{N} 20^{\circ} \mathrm{E}$ and southward dips of $40^{\circ}-66^{\circ}$. Chiayang Formation, composed of gray slate, conforms to the Dagan Sandstone. Tachien Sandstone, 


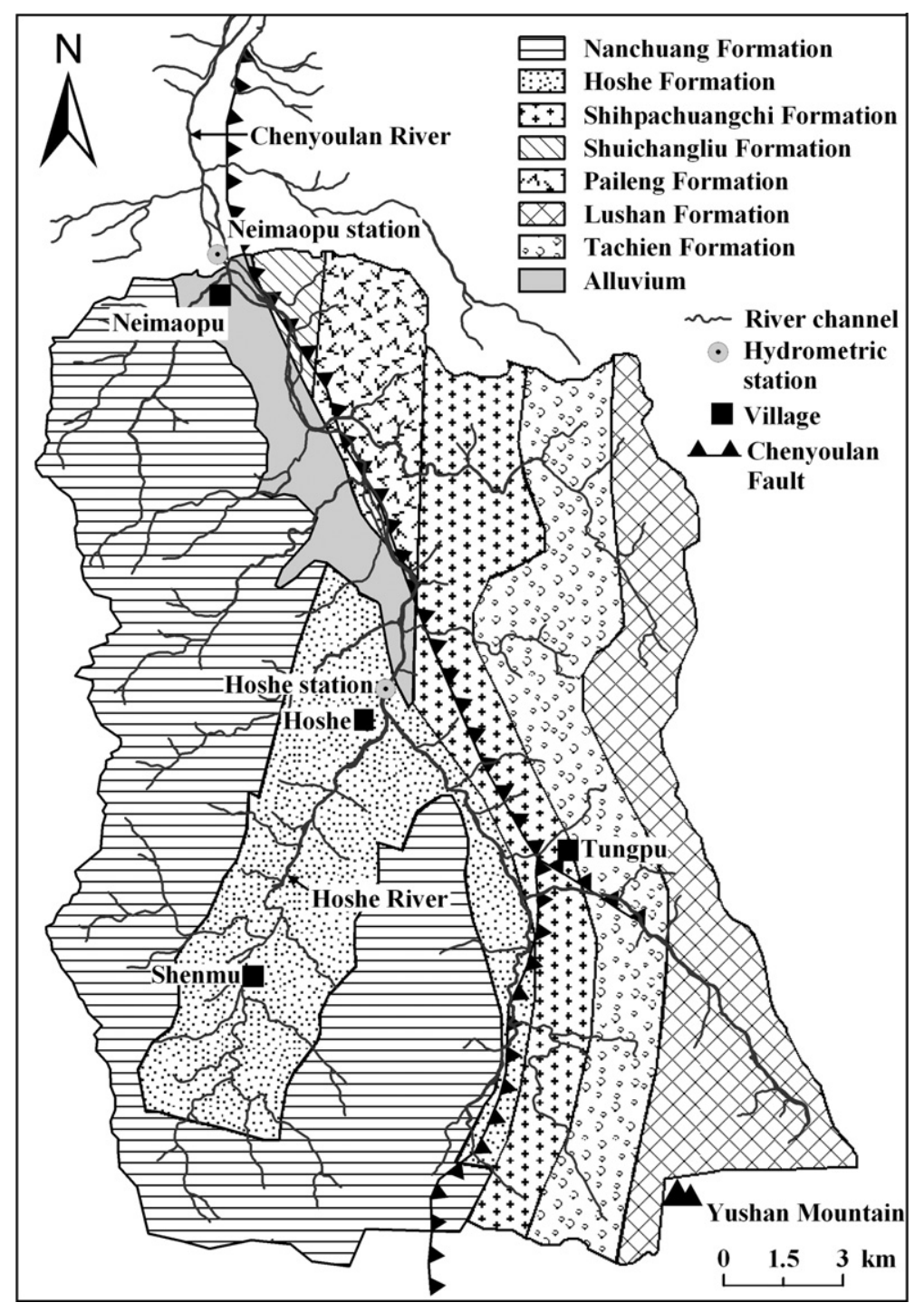

Fig. 2. Geological map of the Chenyoulan River basin and location of hydrometric station.

composed of meta-sandstone and slate, has strikes of $\mathrm{N} 30^{\circ} \mathrm{W}-$ $\mathrm{N} 20^{\circ} \mathrm{E}$ and southward dips of $30^{\circ}-60^{\circ}$. Shihpachuangchi Formation, composed of black and gray slate, has strikes of $\mathrm{N} 29^{\circ} \mathrm{E}-\mathrm{N} 57^{\circ} \mathrm{W}$ and southward dips of $51^{\circ}$. Shuichangliu Formation and Paileng Formation, composed of gray hard slate and meta-sandstone, have strikes of $\mathrm{N} 49^{\circ} \mathrm{E}-\mathrm{N} 9^{\circ} \mathrm{E}$ and southward dips of $50^{\circ}-65^{\circ}$. There are more than two sets of discontinuity in the rock mass of Shuichangliu Formation and Paileng Formation. The discontinuity density averages $16.9 \mathrm{~m}^{-3}$ for these six formations, indicating that the rock mass on the hillslope is fracturing considerably in the Chenyoulan River catchment.

The terrain to the west of the Chenyoulan fault is classified as Neogene sedimentary rock of the Western Foothills, composed of the shale and sandstone. The major formations west of Chenyoulan fault are Nanchuang Formation, Hoshe Formation and Alluvium. Shale and cemented sandstone are the dominant lithologies in the area. Nanchuang Formation, located in the westernmost part of the Chenyoulan River basin, has strikes of $\mathrm{N} 17^{\circ} \mathrm{E}-\mathrm{N} 39^{\circ} \mathrm{E}$ and northward dips of $48^{\circ}-71^{\circ}$. The major lithology of Nanchuang Formation is composed of thick sandstone and shale. The discontinuity density of Nanchuang Formation averages $10.4 \mathrm{~m}^{-3}$. Hoshe Formation, which outcrops in the upper part of the Chenyoulan River catchment, has strikes of $\mathrm{N} 50^{\circ} \mathrm{W}-\mathrm{N} 21^{\circ} \mathrm{E}$ and northward dips of $30^{\circ}-80^{\circ}$. The lithology in Hoshe Formation is the same as the composition in Nanchuang Formation. The discontinuity density of Hoshe Formation averages $8.2 \mathrm{~m}^{-3}$. Alluvium is distributed along the main stream of the Chenyoulan River and the confluences of tributaries.

\section{Landslide analysis}

Landslides were mapped from 10 and $20 \mathrm{~m}$ resolution SPOT satellite images with detailed field and air-photo checking in the Chenyoulan River basin (Lin et al., 2004). The $20 \mathrm{~m}$ multispectral and $10 \mathrm{~m}$ panchromatic spatial resolution of SPOT can only be used to map landslides greater than $1600 \mathrm{~m}^{2}$ with accuracy. Omission of landslides smaller than $1600 \mathrm{~m}^{2}$ can result in underestimation of the area and volume of material disturbed. 


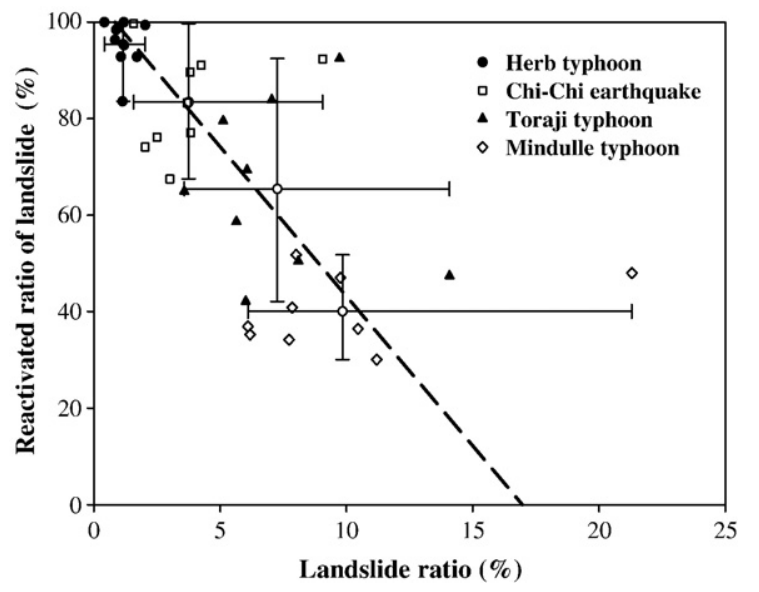

Fig. 3. Ratios of reactivated landslide in the Chenyoulan River basin. Dashed line is regression of all observed data.

We used the landslide ratio, the new generation ratio and the reactivated ratio of landslide to discuss landslide condition. The landslide ratio is defined as the ratio of the total landslide area to the catchment area. We also defined the new generation ratio as the ratio of new landslide area to the total landslide area. Additionally, we defined the reactivated ratio as the ratio of reactivated landslide area to the old landslide area. The formula can be written as follows:

New generation ratio $=\frac{\text { New landslide area after the event }}{\text { Total landslide area after event }} \times 100 \%$

Reactivated ratio $=\frac{\text { Reactivated landslide area after the event }}{\text { Landslide area before the event }} \times 100 \%$

"New landslide area after the event" means that the landslide appeared only after that event; "reactivated landslide area after the event" means that the landslide area was reactivated after that one event; "old landslide area before event" means that landslide already existed before that event.

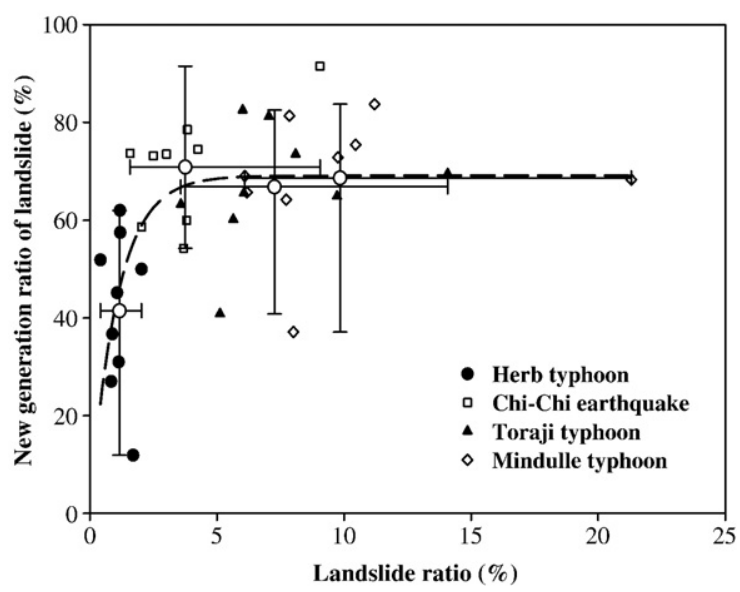

Fig. 4. Ratios of new generation landslide in the Chenyoulan River basin. Dashed line is regression of all observed data.
Table 1

Landslide number, landslide area, landslide ratio, reactivated ratio, and new generation ratio of four typhoon-induced and earthquake-induced events

\begin{tabular}{|c|c|c|c|c|c|}
\hline Events & $\begin{array}{l}\text { Pre-Herb } \\
\text { typhoon }\end{array}$ & $\begin{array}{l}\text { Herb } \\
\text { typhoon }\end{array}$ & $\begin{array}{l}\text { Chi-Chi } \\
\text { earthquake }\end{array}$ & $\begin{array}{l}\text { Toraji } \\
\text { typhoon }\end{array}$ & $\begin{array}{l}\text { Mindulle } \\
\text { typhoon }\end{array}$ \\
\hline Landslide number & 716 & 1168 & 2321 & 3735 & 2120 \\
\hline Landslide area $\left(10^{6} \mathrm{~m}^{2}\right)$ & 2.99 & 4.59 & 12.85 & 24.43 & 31.58 \\
\hline Landslide ratio (\%) & 0.82 & 1.26 & 3.53 & 6.71 & 8.67 \\
\hline Reactivated ratio (\%) & - & 93.49 & 83.16 & 64.61 & 40.55 \\
\hline $\begin{array}{l}\text { New generation } \\
\text { ratio }(\%)\end{array}$ & - & 39.17 & 70.31 & 66.03 & 68.62 \\
\hline $\begin{array}{l}\text { Exponent of landslide } \\
\text { area probability, } \gamma\end{array}$ & 1.88 & 1.99 & 1.83 & 1.86 & 1.88 \\
\hline
\end{tabular}

Calculation and statistics of landslide number, area, landslide ratio, reactivated ratio and new generation ratio indicate that landslides continue to expand in the Chenyoulan River basin. The landslide area has increased 2.8 times since September 1999.

Furthermore, after typhoons Toraji and Mindulle, the landslide area increased by 1.9 times and 1.3 times, respectively. After typhoon Herb, the reactivated ratio of landslide reached $93.5 \%$ and, following the Chi-Chi earthquake, the ratio of new generation landslide decreased progressively. The reactivated ratio decreased to $40.0 \%$ after typhoon Mindulle (Fig. 3). Moreover, the ratio of new generation landslides grew from $41.0 \%$ to $70.0 \%$ after the earthquake (Fig. 4). Following typhoons Toraji and Mindulle, the ratios of new generation landslide were $66.0 \%$ and $68.2 \%$ (Table 1), respectively.

The decrease in reactivated ratio may indicate that the activity of old landslides became moderated or had stopped. The landslide ratio in the Chenyoulan River basin is on the rise, and the new generation ratio maintained at high ratio about $70 \%$.

The landslide areas mapped following the Chi-Chi earthquake and typhoons Herb, Toraji and Mindulle display a magnitudeprobability distribution that can be described by a power law over the approximately three orders of area magnitude for which reliable measurements are available (Fig. 5). The power law

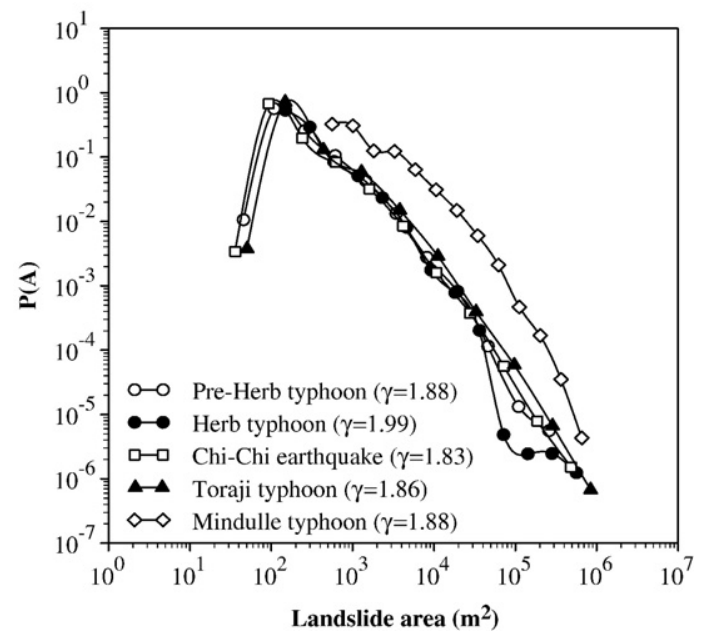

Fig. 5. Probability distribution of landslide areas during typhoon Herb, Chi-Chi earthquake, typhoon Toraji, and typhoon Mindulle. $\gamma$ is the regression exponents of power law. 
Table 2

Mean, minimum, maximum rock strength, and ISRM classification of each litho-formation

\begin{tabular}{|c|c|c|c|c|c|}
\hline Formation & $\begin{array}{l}\text { Nanchuang Formation } \\
\text { sandstone (MPa) }\end{array}$ & $\begin{array}{l}\text { Nanchuang Formation } \\
\text { shale }(\mathrm{MPa})\end{array}$ & $\begin{array}{l}\text { Hoshe Formation } \\
\text { sandstone (MPa) }\end{array}$ & $\begin{array}{l}\text { Hoshe Formation } \\
\text { shale }(\mathrm{MPa})\end{array}$ & $\begin{array}{l}\text { Metamorphic } \\
\text { terrain (MPa) }\end{array}$ \\
\hline Mean & 69.88 & 6.37 & 96.47 & 43.14 & 101.77 \\
\hline Maximum & 116.31 & 9.80 & 156.52 & 48.42 & 178.41 \\
\hline Minimum & 29.40 & 4.00 & 50.46 & 37.91 & 45.18 \\
\hline Strength classification of ISRM & $\mathrm{R}_{3}$ & $\mathrm{R}_{1}$ & $\mathrm{R}_{4}$ & $\mathrm{R}_{3}$ & $\mathrm{R}_{5}$ \\
\hline
\end{tabular}

distribution is valid over a wide range of landslide areas (Guzzetti et al., 2002), and is used to discuss the dominant area of landslide. This probability distribution may be written in a cumulative form (Hovius et al., 1997),

$P\left(A \geq A_{c}\right)=\kappa A^{-\gamma}$

where $P\left(A \geq A_{C}\right)$ is the probability of the number of landslides of magnitude greater than or equal to $A_{c}, \kappa$ is the frequency of landslide per unit area, and $\gamma$ is a dimensionless scaling exponent. We define $A_{c}=2000 \mathrm{~m}^{2}$, and obtain the best fitting power law model by linear regression.

For landslides from the Chi-Chi earthquake and the typhoons, the scaling exponents, $\gamma$, were estimated using the maximum likelihood method (Riley et al., 2002) as higher than 1.5 over a range between $2000 \mathrm{~m}^{2}$ and $1 \times 10^{6} \mathrm{~m}^{2}$ (Table 1). These exponents indicate that small and frequent landslides are really and volumetrically important in the Chenyoulan River basin.

\section{Uniaxial compressive strength}

The field investigation indicates that the depth of landsliding in the Chenyoulan River catchment is deeper than the thickness of surface soil and colluvium after the 2004 typhoon Mindulle. Therefore, we performed the uniaxial compressive strength (UCS) test on 128 sets of rock samples obtained from every formation in Chenyoulan catchment so as to find a correlation between mechanical strength of the batholith in each formation and landslide. Each set of rock samples include 3 to 5 rock cores which have a length of $30 \mathrm{~cm}$ and a radius of $15 \mathrm{~cm}$.

For 37 sets of sandstone samples from Nanchuang Formation, the average UCS is $70 \mathrm{MPa}$, while for 12 sets of shale samples, it is less than $10 \mathrm{MPa}$. The ratio of sandstone to shale in Nanchuang Formation is about 1:1, therefore the average UCS for the entire Nanchuang Formation is calculated to be $42 \mathrm{MPa}$.

For 32 sets of sandstone samples from Hoshe Formation, the average UCS is $96 \mathrm{MPa}$, while for 10 sets of shale samples, it varied between 37 and $49 \mathrm{MPa}$. The ratio of sandstone to shale in Hoshe Formation is also $1: 1$, hence the average UCS of Hoshe Formation is calculated to be $70 \mathrm{MPa}$. For 37 sets of metamorphic rock samples obtained from east region of Chenyoulan catchment, the average UCS is $102 \mathrm{MPa}$.

The comparatively lower UCS $(<10 \mathrm{MPa})$ of shale in Nanchuang Formation is a major factor causing the average UCS of the entire Nanchuang Formation to be lower than that of the other formations. Although the average UCS of metamorphic rock is the highest in Chenyoulan catchment, the variation of UCS of metamorphic rock there is the greatest because the metamorphic rock includes high UCS metamorphic sandstone and low UCS slate (Table 2).

\section{Analysis of Normalized Difference Vegetation Index}

On the hillslope disturbed by landsliding, the vegetation would be wasted. The density of vegetation can be another target to understand the degree of landsliding effect. Green leaves commonly have larger reflection in the near-infrared light than in the infrared light. As the green plants come over heavy rainstorm, become diseased or die, they would reflect significantly less in the near-infrared light. A range of satellite derived vegetation indices has been widely used to classify land cover. We used SPOT satellite imagines to count the density of vegetation, which could be indirectly calculated from the visible and near-infrared light reflected by vegetation as a Normalized Difference Vegetation Index (NDVI). The NDVI results can assist in determining the density of green plant presence using the wavelengths difference. The formula used to count can be written as follows (Deering, 1978).

$\mathrm{NDVI}=\frac{\text { near-infrared reflection }(\mathrm{NIR})-\text { infrared reflection }(\mathrm{IR})}{\text { near-infrared reflection }(\mathrm{NIR})+\text { infrared reflection }(\mathrm{IR})}$

NIR and IR can be investigated in the SPOT satellite images by observing the distinct colors in wavelengths reflected by the plants. The calculation of NDVI for a given pixel in the SPOT satellite images always results in a number that ranges from -1 to +1 . Because the variations of photosynthetic activity in

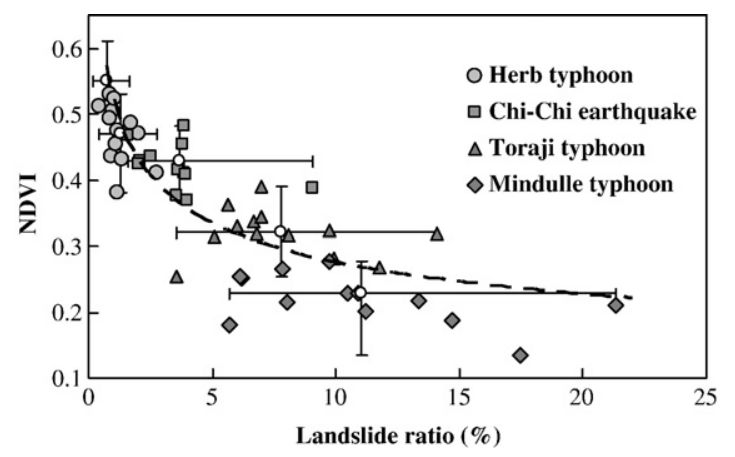

Fig. 6. NDVI value and landslide ratio of each sub-catchment in Chenyoulan catchment. Dashed line is regression of all observed data. 
Table 3

Statistics of sediment discharge and flow discharge of four typhoons which induce hazardous landslides

\begin{tabular}{|c|c|c|c|c|c|c|}
\hline Events & $\begin{array}{l}\text { Date } \\
\text { (days) }\end{array}$ & $\begin{array}{l}\text { Total sediment } \\
\text { discharge }(\mathrm{t})\end{array}$ & $\begin{array}{l}\text { Calculated } \\
\text { date (days) }\end{array}$ & $\begin{array}{l}\text { Average sediment discharge } \\
\text { per day }\left(\mathrm{t} \mathrm{day}^{-1}\right)\end{array}$ & $\begin{array}{l}\text { Average flow } \\
\text { discharge }\left(\mathrm{m}^{3} \mathrm{~s}^{-1}\right)\end{array}$ & $\begin{array}{l}\text { Unit sediment } \\
\text { discharge }\left(\mathrm{t} \mathrm{m}^{-3} \mathrm{~s}^{-1}\right)\end{array}$ \\
\hline Herb typhoon & $7 / 29-8 / 1(4)$ & $28,743,058$ & $7 / 31-8 / 2(3)$ & $9,581,019$ & 913.70 & 31,457 \\
\hline Toraji typhoon & $7 / 28-7 / 31(4)$ & $11,555,922$ & $7 / 30-8 / 2(4)$ & $2,888,980$ & 254.88 & 45,338 \\
\hline Mindulle typhoon & $6 / 28-7 / 3(6)$ & $9,918,494$ & $6 / 28-7 / 5(8)$ & $1,239,811$ & 203.28 & 48,791 \\
\hline Aere typhoon & $8 / 23-8 / 26(4)$ & $34,146,534$ & $8 / 23-9 / 3(12)$ & $2,845,544$ & 897.57 & 38,043 \\
\hline
\end{tabular}

different seasons impact the calculation of NDVI, we selected SPOT images taken in the months from June to December.

Prior to 1996 typhoon Herb, the result of NDVI analysis in Chanyoulan River catchment ranged between -0.25 and 0.77 , with an average of 0.55 . After typhoon Herb, the average value of NDVI became 0.47 ; moreover, the average dropped to 0.43 , 0.32 and 0.23 after the 1999 Chi-Chi earthquake, 2001 typhoon Toraji and 2004 Typhoon Mindulle, respectively (Fig. 6). These results show that average NDVI value after any rainstorm or earthquake event decreased continuously during the period from 1996 to 2004, signifying that the vegetation cover condition was impacted and reduced. The variation of NDVI value in different sub-catchments may result from the diversity of vegetation, geomaterials, gradient, and other factors.

In the Chenyoulan catchment, as the landslide ratio increases with the successive rainstorms and heavy earthquake, the NDVI values decrease. We attribute this to mass erosion resulting from landsliding; the resulting wastage of vegetation causes the drop of NDVI value. Further, we find that the variation of NDVI values in sub-catchments after rainstorms are higher than the variation after heavy earthquake. Hence, subsequent rainstorms cause more divergent destruction of vegetation in each subcatchment, and this may be influenced by precipitation distribution and path of typhoon.

\section{Estimation of sediment discharge}

Hydrometric data, including sediment concentration and flow discharge, are required in order to apply the Monthly Weighted Average Method (MWA) (Cohn, 1995) to estimate sediment discharge. The sampling frequency of Water Resource Agency (WRA) increases in the summer months (from May to October). Employing an average of monthly average can eliminate bias associated with increased sampling frequency. The data used in our study were obtained from the hydrometric stations of the Water Resources Agency in the Chenyoulan River watershed. The observers of WRA get the suspended sediment sample average $30 \pm 2$ times per year and they also measure the flow discharge as they get the suspended sediment sample (WRA, 2007). The formula used to calculate the sediment discharge can be written as follows,

$E_{\mathrm{MWA}}=\frac{1}{12} \sum_{i}^{12}\left(\frac{1}{m_{i}} \sum_{j=1}^{m_{i}} Q_{s i j}\right)$

where $E_{\mathrm{MWA}}$ is the calculated amount of sediment discharge $\left(\mathrm{t}\right.$ day $\left.{ }^{-1}\right), m_{i}$ is the measured times number frequency per month, and $Q_{s i j}$ is the measured value of sediment discharge $\left(\mathrm{t} \mathrm{day}^{-1}\right)$.
Lacking sufficient measurement data from the typhoon periods to calculate the typhoon-induced sediment discharge, we used the Rating Curve Method (Walling, 1977) to estimate sediment discharge during the typhoon periods. The Rating Curve Method is useful when an empirically calibrated power law relation between the flow discharge and the sediment concentration can be defined. The standard formula is

$Q_{s}=a Q^{c}$

where $Q_{s}$ is suspended sediment concentration and $Q$ is flow discharge. The formula is linearized by taking the logarithm of each coordinate axis. The parameters $a$ and $c$ are determined by using least-square regression. Then, the $Q_{s}$ would be obtained by back-transformation of the measurements of flow discharge

Table 4

Average flow discharge and daily sediment discharge in the period of typhoon

\begin{tabular}{|c|c|c|c|}
\hline Typhoon & Date & $\begin{array}{l}\text { Sediment } \\
\text { discharge (t) }\end{array}$ & $\begin{array}{l}\text { Average flow } \\
\text { discharge }\left(\mathrm{m}^{3} \mathrm{~s}^{-1}\right)\end{array}$ \\
\hline \multirow[t]{4}{*}{ Herb } & $1996 / 7 / 31$ & 405,716 & 186.26 \\
\hline & 1996/8/1 & $25,727,177$ & 1875.83 \\
\hline & $1996 / 8 / 2$ & $2,610,166$ & 698.33 \\
\hline & Total sediment discharge & $28,743,058$ & \\
\hline \multirow[t]{7}{*}{ Toraji } & $2001 / 7 / 28$ & 2768 & 20.07 \\
\hline & $2001 / 7 / 29$ & 1913 & 17.08 \\
\hline & $2001 / 7 / 30$ & $10,426,733$ & 730.38 \\
\hline & $2001 / 7 / 31$ & 910,888 & 251.99 \\
\hline & $2001 / 8 / 1$ & 164,860 & 119.49 \\
\hline & $2001 / 8 / 2$ & 53,442 & 73.07 \\
\hline & Total sediment discharge & $11,555,922$ & \\
\hline \multirow[t]{9}{*}{ Mindulle } & $2004 / 6 / 28$ & 455,123 & 146.12 \\
\hline & $2004 / 6 / 29$ & 443,531 & 144.56 \\
\hline & $2004 / 6 / 30$ & 433,875 & 143.37 \\
\hline & $2004 / 7 / 1$ & 426,486 & 142.42 \\
\hline & $2004 / 7 / 2$ & 738,302 & 172.00 \\
\hline & $2004 / 7 / 3$ & $1,964,797$ & 252.50 \\
\hline & $2004 / 7 / 4$ & $4,862,211$ & 356.19 \\
\hline & $2004 / 7 / 5$ & 594,170 & 221.98 \\
\hline & Total sediment discharge & $9,918,494$ & \\
\hline \multirow[t]{13}{*}{ Aere } & $2004 / 8 / 23$ & 100,308 & 99.77 \\
\hline & $2004 / 8 / 24$ & 596,613 & 222.39 \\
\hline & $2004 / 8 / 25$ & $4,268,531$ & 874.64 \\
\hline & $2004 / 8 / 26$ & $3,003,188$ & 637.11 \\
\hline & $2004 / 8 / 27$ & $4,884,710$ & 987.66 \\
\hline & $2004 / 8 / 28$ & $4,930,563$ & 996.01 \\
\hline & $2004 / 8 / 29$ & $4,884,710$ & 987.66 \\
\hline & $2004 / 8 / 30$ & $5,116,449$ & $1,029.79$ \\
\hline & $2004 / 8 / 31$ & $3,584,263$ & 747.22 \\
\hline & 2004/9/1 & $1,543,763$ & 349.75 \\
\hline & $2004 / 9 / 2$ & $1,202,453$ & 304.76 \\
\hline & $2004 / 9 / 3$ & 30,984 & 58.83 \\
\hline & Total sediment discharge & $34,146,534$ & \\
\hline
\end{tabular}




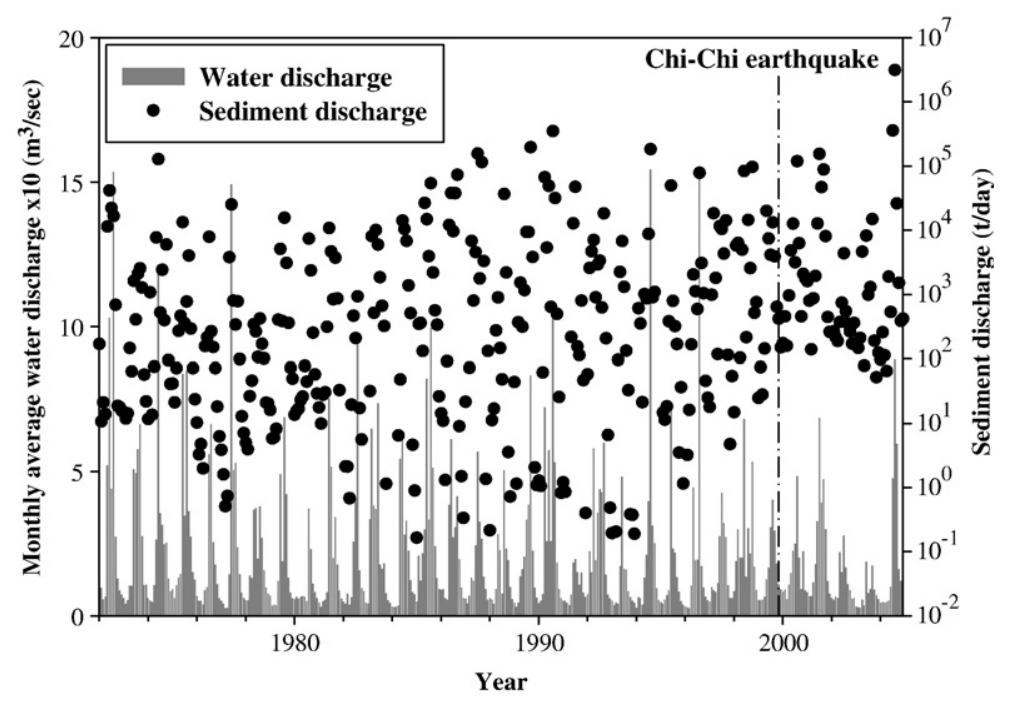

Fig. 7. The record of water discharge and sediment discharge in the period from 1972 to 2004.

$Q$. The relation between flow discharge and sediment concentration was constructed by the measured data of one year. For the case of typhoon Mindulle, the thirty measured data of 2004 are used to construct the rating curve of 2004, and then the sediment discharge during typhoon Mindulle is estimated by the rating curve of 2004 and the hourly flow discharge during typhoon Mindulle. We estimated the sediment discharge of 4 typhoons, including typhoons Herb, Toraji, Mindulle and Aere from 1996-2004.

Estimation of data at the hydrometric station shows that, during the period of 1972-2004, the average annual sediment discharge at the downstream Neimaopu station was $6.2 \mathrm{Mt} \mathrm{yr}^{-1}$, while the annual sediment discharge was $107 \mathrm{Mt}$ in 2004. If we excluded the 2004 data from our estimation, the annual

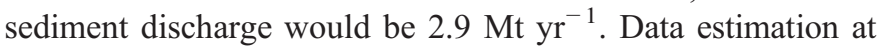

the upstream Hoshe station shows that, during the period from 1972 to 2000, the average annual sediment discharge was $0.5 \mathrm{Mt} \mathrm{yr}^{-1}$, that is, one-tenth of the average annual sediment discharge at the downstream Neimaopu station. Nevertheless, the annual sediment discharge at Hoshe station was $2.7 \mathrm{Mt} \mathrm{yr}^{-1}$ in 1994, but less than $100 \mathrm{t} \mathrm{yr}^{-1}$ in 1987. The above-mentioned condition shows that the variation of the annual sediment discharge at the Hoshe station is great. We also estimated sediment discharges during major storms, including 1996 typhoon Herb, 2001 typhoon Torji, 2004 typhoon Mindulle and 2004 typhoon Aere (Table 3).

During 1996 typhoon Herb, the catchment of upstream Neimaopu station supplied 28.7 Mt of sediment discharge over a period of 3 days (Table 4). Specifically on 1 August, 25.7 Mt of sediment was delivered downstream, with the average

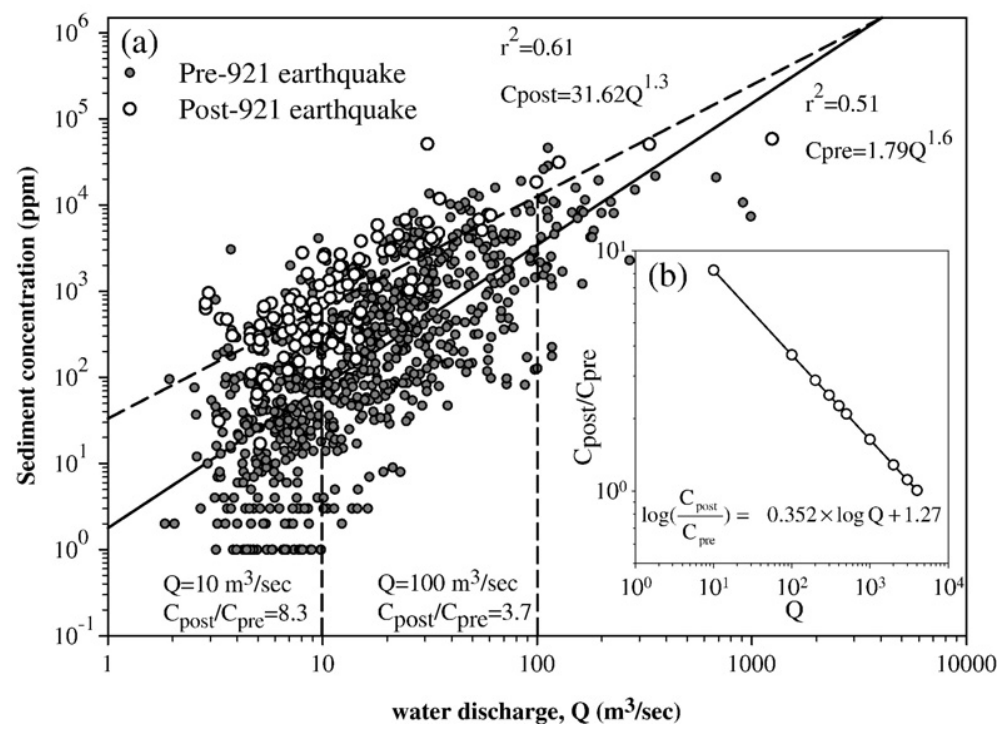

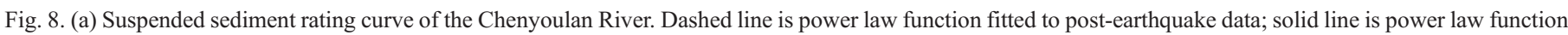
fitted to pre-earthquake data. (b) The concentration ratio of pre-earthquake and post-earthquake. Solid line is power law regression. 
sediment concentration for this day reaching $158.7 \times 10^{3} \mathrm{ppm}$, much higher than the average annual sediment concentration of $2.3 \times 10^{3} \mathrm{ppm}$. During 2001 typhoon Toraji, the catchment upstream of Neimaopu station supplied 11.6 Mt of sediment, with $10 \mathrm{Mt}$ of sediment delivered downstream on 30 July. The total sediment during typhoon Toraji was less than that during typhoon Herb, but the average flow discharge during typhoon Toraji was $254.9 \mathrm{~m}^{3} \mathrm{~s}^{-1}$, only a quarter of the average flow discharge during typhoon Herb. The unit concentration of sediment during typhoon Toraji was $4.5 \mathrm{Mt} \mathrm{m}^{-3} \mathrm{~s}^{-1}$ greater than the unit concentration during the typhoon Herb.

During 2004 typhoon Mindulle from 28 June to 3 July, $4.5 \mathrm{Mt}$ of sediment were delivered to the downstream area. However, storms following typhoon Mindulle induced 4.9 Mt of sediment on 4 July. During the period of typhoon Aere, the upstream catchment of Neimaopu station yielded $34 \mathrm{Mt}$ of sediment, with an average daily sediment discharge of $2.8 \mathrm{Mt} \mathrm{day}^{-1}$. The unit sediment concentrations during typhoons Mindulle and Aere were $4.8 \mathrm{Mt} \mathrm{m}^{-3} \mathrm{~s}^{-1}$ and $3.8 \mathrm{Mt} \mathrm{m}^{-3} \mathrm{~s}^{-1}$, respectively.

\section{The change of sediment discharge}

For the relationship between average flow discharge and measured sediment discharge during the period of 1972-2004, we found that post-earthquake measured sediment discharges were greater than $1 \mathrm{t} \mathrm{day}^{-1}$ (Fig. 7), which differed discernibly from the pre-earthquake measured sediment discharges, which were frequently less than $1 \mathrm{t}^{\text {day }}{ }^{-1}$.

In the Chenyoulan River basin, the sediment discharges increased after the Chi-Chi earthquake (Fig. 8a). The average annual sediment discharge was $2.9 \mathrm{Mt} \mathrm{yr}^{-1}\left(7.9 \times 10^{3} \mathrm{t} \mathrm{yr}^{-1}\right.$ $\mathrm{km}^{-2}$ ) in the period of 1972 to 1999 , and it was $37.8 \mathrm{Mt} \mathrm{yr}^{-1}$ $\left(103 \times 10^{3} \mathrm{t} \mathrm{yr}^{-1} \mathrm{~km}^{-2}\right)$ in the period from 2000 to 2004 . The change indicates that sediment discharges increased by 13 times after the earthquake. The average annual sediment discharge of the Choshui River in central Taiwan was $5.4 \mathrm{Mt} \mathrm{yr}^{-1}\left(1.8 \times 10^{3} \mathrm{t}\right.$ $\mathrm{yr}^{-1} \mathrm{~km}^{-2}$ ) in the period from 1986 to 1999 , and it increased by 2.6 times in the period between the Chi-Chi earthquake and the end of 2001 (Dadson et al., 2004). The area of the Choshui River basin is $2989 \mathrm{~km}^{2}, 8$ times greater than the Chenyoulan River catchment. In addition to the relationship between the measured flow discharge and the sediment concentration, the post-seismic concentration increased, and the ratio of preseismic and post-seismic concentration $\left(C_{\text {post }} / C_{\text {pre }}\right)$ can be described by a power law formula with measured flow discharge (Fig. 8b). This formula can be written as follows,

$\log \left(\frac{C_{\text {post }}}{C_{\text {pre }}}\right)=-0.352 \times \log Q+1.27$

where $C_{\text {post }}$ is the post-seismic sediment concentration, $C_{\text {pre }}$ is the pre-seismic sediment concentration, and $Q$ is the measured flow discharge. The exponential decay reveals that the ratio, $C_{\text {post }} / C_{\text {pre }}$, is lower when the flow discharge is higher.

When the flow discharge is less than $100 \mathrm{~m}^{3} \mathrm{~s}^{-1}$, post-seismic sediment concentration is 4 times higher than pre-seismic concentration with the same flow discharge. Dadson et al. (2004) discussed the average over a 6-month period of sediment concentration from 1986 to 2002 in the Choshui River, and found that the data for winter seasons displayed an exponential decay in sediment concentration from the elevated post-seismic value to the pre-1999 winter mean. Although the Chenyoulan River is a tributary of the Choshui River, its condition of sediment discharge during winter seasons is not the same as that of the Choshui River.

Moreover, the average sediment discharge for post-earthquake winter seasons (1999-2004) was less than the amount for all available recorded winter seasons (1972-2004). That may have been because the average annual precipitation for 1999 to 2004 was also less than the amount for 1972 to 2004. This also

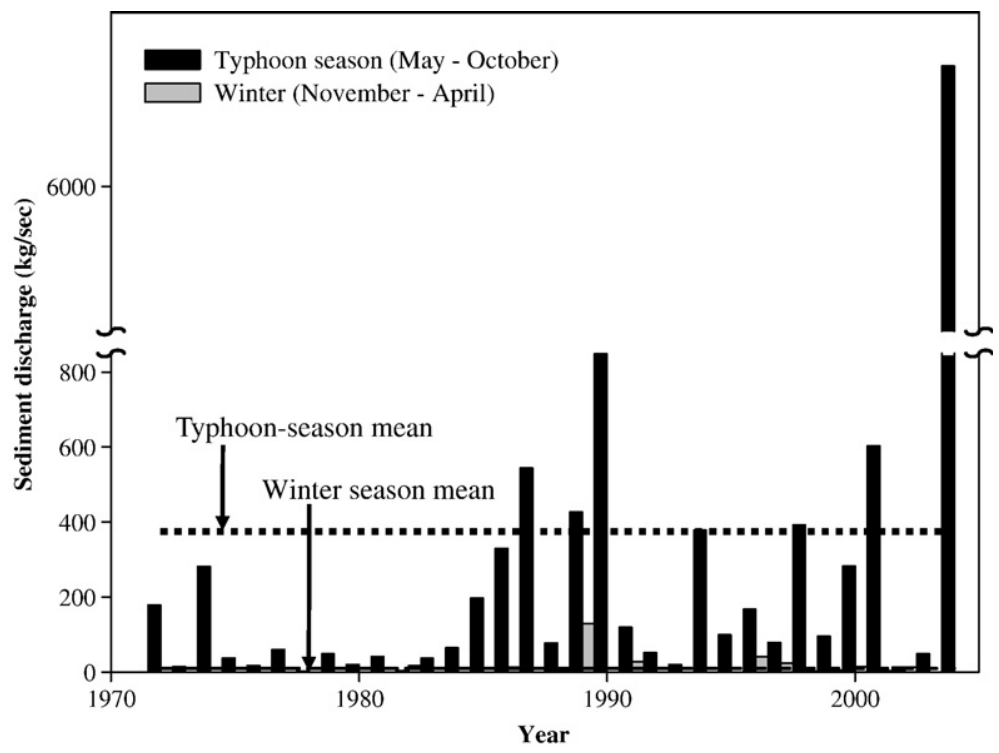

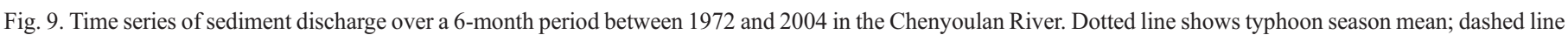
shows winter season mean. 


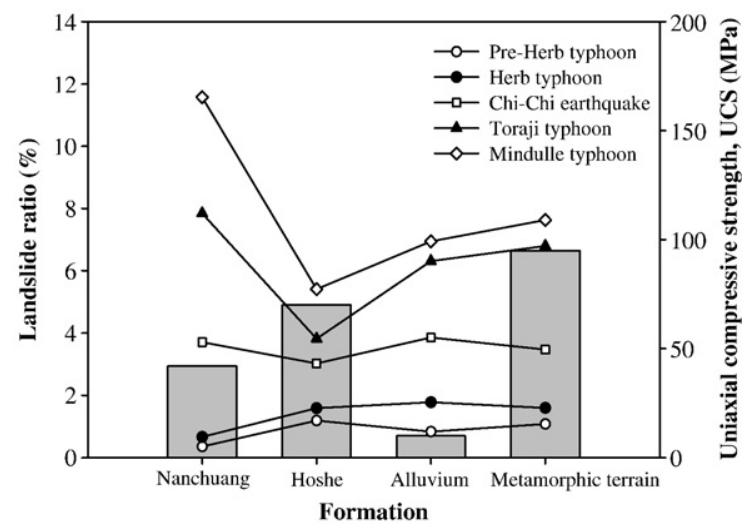

Fig. 10. Landslide ratios of four formations in four typhoon-induced and earthquake-induced landslide and UCS of four formations.

indicates that pattern of sediment discharge during winter seasons is determined by the precipitation.

Additionally, from the comparison of the average over a 6month period of sediment discharge, we found that in 1999 the sediment discharge of typhoon season (from May to October) was 15263 times the sediment discharge of winter season (from December to following April), and the average sediment discharge of typhoon seasons was 38 times the average sediment discharge of winter seasons from 1972 to 2004. This reveals that sediment discharges of typhoon seasons and winter seasons display enormous disparity in the Chenyoulan River basin (Fig. 9).

\section{Discussion}

In Nanchuang Formation, the typhoon Mindulle landslide ratio was 17 times the typhoon Herb landslide ratio (Fig. 10). But, in Hoshe Formation, the landslide ratio from typhoon Herb to typhoon Mindulle increased less than 5 times. The increase of landslide ratio for the Nanchuang Formation is discernibly greater than that of the Hoshe Formation in the period from 1996 typhoon Herb to 2004 typhoon Mindulle. This observation shows that the landslide ratio difference between Nanchuang Formation and Hoshe Formation may be related to the fact that the average uniaxial compressive strength of Nanchuang Formation is the lowest among three formations. In Alluvium, with sediment strength less than $10 \mathrm{MPa}$ (CGS, 2003), the landslide ratio also increased by less than 5 times from typhoon Herb to typhoon Mindulle.

Keefer (2000) suggested that the proportion of surface area disturbed by landsliding increases with proximity to the earthquake epicenter and earthquake fault and the decrease becomes more obvious with proximity to the epicenter. Dadson et al. (2004) studied the landslide data of Chi-Chi earthquake, and found that the decrease in area affected by landsliding away from the Chelungpu fault was rapid at distances in excess of $20 \mathrm{~km}$ from the fault. In the Chenyoulan River basin, after Chi-Chi earthquake, the landslide ratio decreased at increased distances from the Chelungpu fault and also decreased with the decay in peak vertical ground acceleration (PGA) (Lee et al., 1999).

Once the distance away from fault exceeded $20 \mathrm{~km}$ and PGA was lower than $0.2 \mathrm{~g}$, the landslide ratio decreased to less than $1 \%$ quickly (Fig. 11). This was particularly evident after typhoon Toraji. Moreover, once the distance away from fault exceeded $20 \mathrm{~km}$ and PGA was lower than $0.2 \mathrm{~g}$, the landslide ratio of typhoon Toraji decreased $7.2 \%$ more quickly than the decrease of the landslide ratio of the earthquake. Nevertheless, after typhoon Mindulle, this appearance of decay of landslide ratio was moderated. The observation of a stronger earthquakerelated signal in the typhoon Toraji-induced landslide distribution suggests that, even in areas that experienced no landsliding during an earthquake, the substrate was preconditioned to fail.

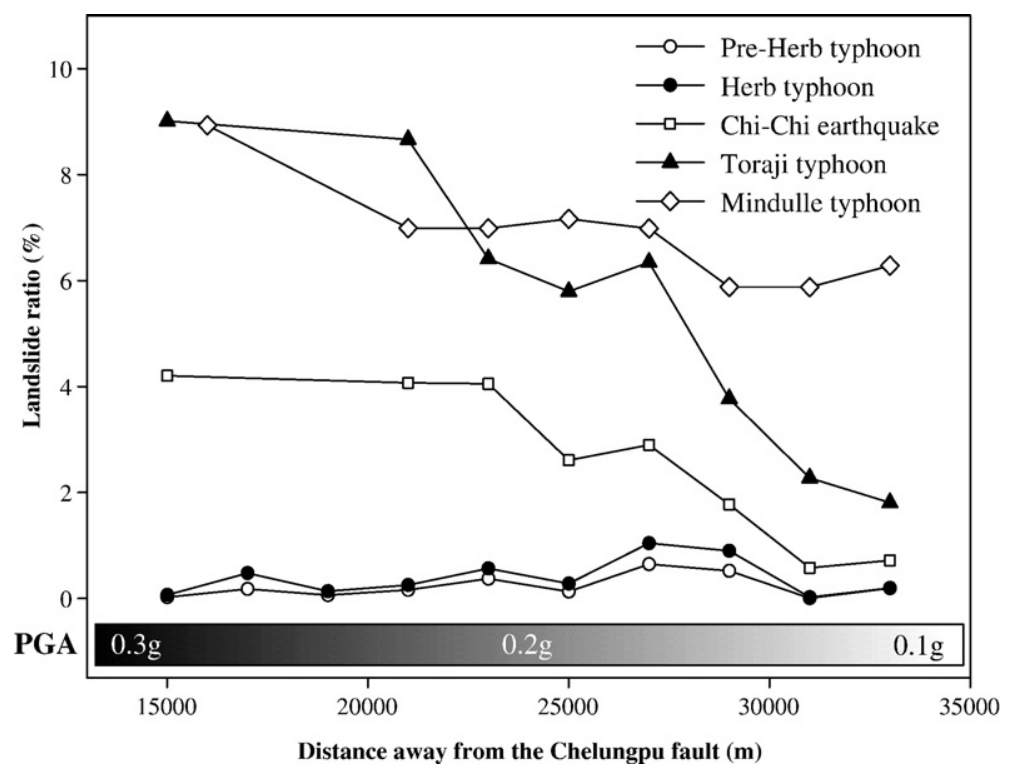

Fig. 11. Landslide ratios in response to earthquake with distance from Chelungpu fault. 


\section{Conclusion}

The probability distribution of landslide area for four events, including the 1996 typhoon Herb, 1999 Chi-Chi earthquake, 2001 typhoon Toraji, and 2004 typhoon Mindulle, correlating well with a power law relation, regression exponents less than 1.5 , indicates that the landslide condition in the Chenyoulan River basin is dominated by small and frequent landslides. During the period from Chi-Chi earthquake to typhoon Mindulle, the ratio of new generation landslides in the Chenyoulan River basin increased to $70 \%$ and then maintained at $70 \%$, while the ratio of reactivated landslide decreased to $40 \%$. We believe that landslides in the Chenyoulan River basin are still affected by the Chi-Chi earthquake. Continuously expanding landslide wastes the mass and vegetation, and enlarges non-vegetation-covered land. Further, the decrease of NDVI value from 1996 to 2004 can reflect this expansion of landsliding area and transformation of landform. The preearthquake average annual sediment discharge was $2.9 \mathrm{Mt} \mathrm{yr}^{-1}$, while the post-earthquake value was $37 \mathrm{Mt} \mathrm{yr}^{-1}$. Hence, the average annual sediment increased by 13 times, while the concentration of sediment increased by 4 times after the earthquake.

In the Chenyoulan River basin, the average uniaxial compressive strength of Nanchuang Formation, at $42 \mathrm{MPa}$, is lower than the average uniaxial compressive strength of Hoshe Formation and metamorphic formations, and the increase in the landslide ratio of Nanchuang Formation is higher than the increase of Hoshe Formation and metamorphic formations. Hence, landslide ratio is intimately related with the uniaxial compressive strength. The relative landslide ratio is also intimately related with the discontinuous plane setting. We conclude that rock strength of the batholith is an important control affecting the scope and frequency of landslide.

At distances exceeding $20 \mathrm{~km}$ from the fault, where PGA was lower than $0.2 \mathrm{~g}$, the landslide ratio of the Chi-Chi earthquake decreased to less than $1 \%$ quickly. This condition was also discernable during typhoon Toraji, suggesting that the affects of the Chi-Chi earthquake are still evident and operative.

\section{Acknowledgements}

The authors would like to express their thanks to S. Dadson, R. H. Chen, S. Lin and C.W. Lin who provided many useful comments and suggestions. The National Science Council, ROC, and Water Resources Agency, Ministry of Economic Affairs, supported this research project financially and supplied the hydrometric data.

\section{References}

CGS, 2003. Construction of engineering geology investigation databank. Central Geological Survey, Ministry of Economic Affairs, Taipei. http:// 61.63.7.135/imoeagis/about/index.htm.

Chen, H., Su, D.I., 2001. Geological factors for hazardous debris flow in Hoser, Central Taiwan. Environmental Geology 40 (9), 1114-1124.

Cohn, T.A., 1995. Recent advances in statistical methods for the estimation of sediment and nutrient transport in rivers. Reviews of Geophysics 33 Suppl., $1117-1130$.

Dadson, S.J., Hovius, N., Chen, H., Dade, W.B., Hsieh, M.L., Willett, S.D., Hu, J.C., Horng, M.J., Chen, M.C., Stark, C.P., Lague, D., Lin, J.C., 2003. Links between erosion, runoff variability and seismicity in the Taiwan orogen. Nature 426, 648-651.

Dadson, S.J., Hovius, N., Chen, H., Dade, W.B., Lin, J.C., Hsu, M.L., Lin, C.W., Horng, M.J., Chen, T.C., Milliman, J., Stark, C.P., 2004. Earthquaketriggered increase in sediment delivery from an active mountain belt. Geology 32 (8), 733-736.

Deering, D.W., 1978. Rangeland reflectance characteristics measured by aircraft and spacecraft sensors. ph.D. Dissertation, Texas A \& M University, College Station, TX, 338.

Geli, L., Bard, P.Y., Jullien, B., 1988. The effect of topography on earthquake ground motion: a review and new results. Bulletin of the Seismological Society of America 78, 42-63.

Guzzetti, F., Malamud, B.D., Turcotte, D.L., Reichenbach, P., 2002. Power-law correlations of landslide areas in central Italy. Earth and Planetary Science Letters 195, 169-183.

Hovius, N., Stark, C.P., Allen, P.A., 1997. Sediment flux from a mountain belt derived by landslide mapping. Geology 25 (3), 231-234.

Keefer, D.K., 2000. Statistical analysis of an earthquake-induced landslide distribution the 1989 Loma Prieta, California event. Engineering Geology 58, 231-249.

Khazai, B., Sitar, N., 2004. Evaluation of factors controlling earthquake-induced landslides caused by Chi-Chi earthquake and comparison with the Northridge and Loma Prieta events. Engineering Geology 71, 79-95.

Lee, W.H., Shin, T.C., Kuo, K.W., Chen, K.C., 1999. CWB Free-Field Strong Motion Data from the 921 Chi-Chi Earthquake, Digital Acceleration Files on CD-ROM. Central Weather Bureau, Taipei.

Lin, C.W., Shieh, C.L., Yuan, B.D., Shieh, Y.C., Liu, S.H., Lee, S.Y., 2004. Impact of Chi-Chi earthquake on the occurrence of landslides and debris flow: example from the Chenyulan river watershed, Nantou, Taiwan. Engineering Geology 71, 49-61.

Riley, K.F., Hobson, M.P., Bence, S.J., 2002. Mathematical Methods for Physics and Engineering, second edition. Cambridge University Press, Cambridge.

Shieh, S.L., 2000. Users' Guide for Typhoon Forecasting in the Taiwan Area (VIII). Central Weather Bureau, Taipei.

Sitar, N., Anderson, S.A., Johnson, K.A., 1992. Conditions leading to the initiation of rainfall-induced debris flows. Geotech. Engrg. Div. Specialty Conf.: Stability and Perf. of slopes and Embankments-II. ASCE, New York, N. Y., pp. 834-839.

Sklar, L.S., Dietrich, W.E., 2001. Sediment and rock strength controls on river incision into bedrock. Geology 29 (12), 1087-1090.

Walling, D.E., 1977. Assessing the accuracy of suspended sediment rating curves for a small basin. Water Resources Research 13 (3), 531-538.

WRA, 2007. Hydrological Yearbook of Taiwan. Water Resources Agency. Ministry of Economic Affairs, Taipei. 